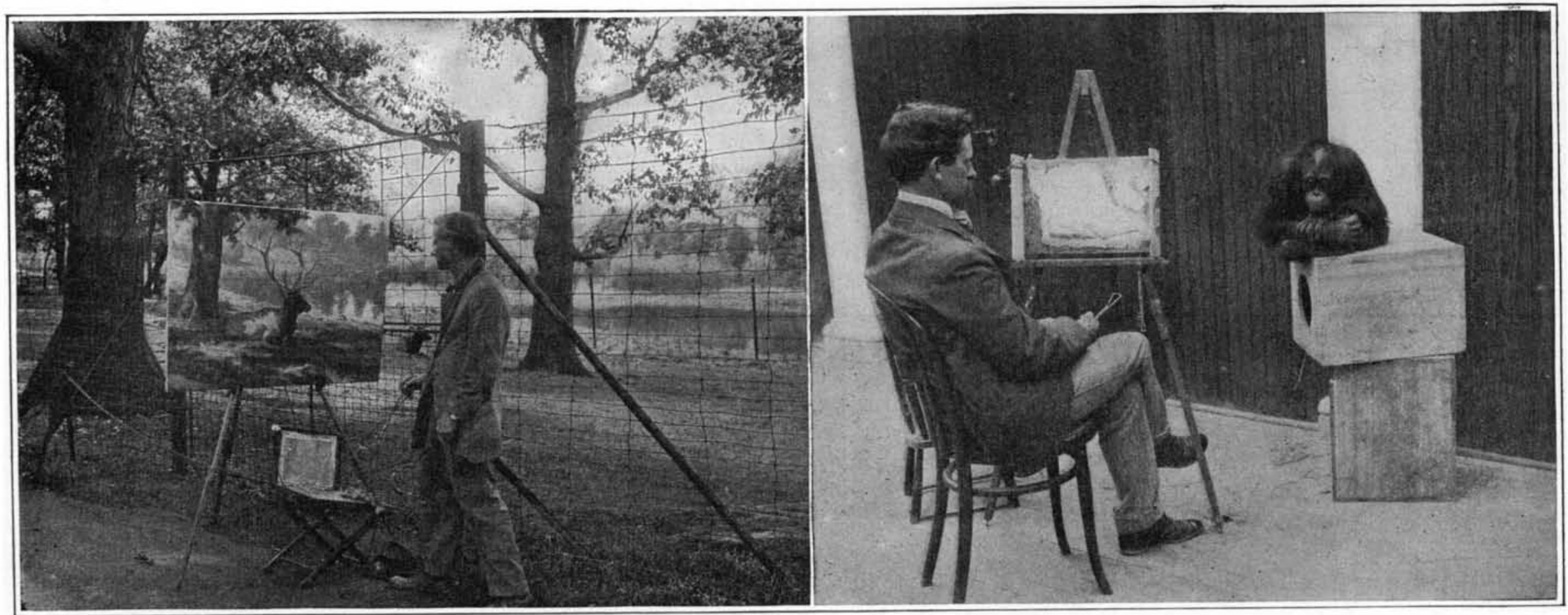

Paul Herzel painting an elk from a live model at Bronx Park

The Zoo helps A. P. Proctor in his study of an orangutan

\title{
Wild Animal Models at the Zoo
}

\author{
How New York's Painters and Sculptors Work from Nature in Their Representations of Wild Life \\ By William T. Hornaday \\ Photographs copyright by the New York Zoological society
}

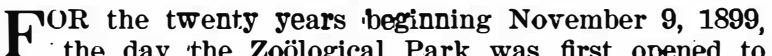
the public, the Zoölogical Society has welcomed all animal painters, sculptors, illustrators, investigators and students. No permits are necessary for anything save the photographing of wild animal models; and all keepers have standing orders that every man is to do everything possible to facilitate the work of painters and sculptors. Even at the best the work of the animal craftsman is difficult, many times it is full of annoyances, and often it is climatically uncomfortable. For the animal craftsman we have no closed hours. They can come in at seven-thirty in the morning, if they don't oversleep, every day in the year, and they can work until dark if they have the endurance. when a roaming beast needs to be penned up for closeup work, we pen it up.

Now, all this coöperation on our part is nothing deserving of thanks, or of anthing more than appreciation. It is our duty to do these things, and they come as being all in the day's work.

Naturally, the magnificent wild animal models of the Zoölogical Park have stimulated the sculpture and painting of wild animals. It is a cold day when there is not at least one painter or sculptor at work, and when business is brisk there may be half a dozen. Never, however, in all these 20 years have I known the animal sculptors and painters of New York to get together to eat or drink something in company, or even for a talkfest. They are not gregarious animals, when it comes to associating in kind. A complete list of the men and women who have utilized our wild animal models and the park as their studio would be a long one.

It was the painters and illustrators who first began to use our animals, and as I recall the past the first ones who worked in the newly-born Zoölogical Park were Carl Rungius and Ernest T. Seton. Mr. Seton's studies were chiefiy of bears, wolves, foxes, otter, beaver and prong-horned antelope.

Mr. Rungius has painted in the park a long list of our largest and finest American animals, and has executed two portraits of "Sultan" and one of "Dinah," the gorilla, for the Zoölogical Society. I think there is no species of North American big game ever in our possession that Mr. Rungius has not painted in our atmosphere. His masterpieces have been of mountain goat, mountain sheep, Alaskan brown hear, polar bear musk-ox, elk, mule deer, American bison, elk and prong-horned antelope. Some day the collection of Rungius paintings in the possession of the New York Zoölogical Society will be the most famous small collection of paintings in all America; and that is all there is time to say about them at present

Mr. A. Plumister Proctor and Mr. Eli Harvey have

done a really "immense" amount of work in the park, and it is a source of sincere pleasure to us all that they have left their records in enduring sculptures on the finest animal 'buildings of our institution. Our architectural sculptors of wild animals began with $\mathrm{Mr}$. Proctor's striking figures of orangutans, kamadryas baboons and mixed monkeys on the Primate House. While this work was in progress, $\mathrm{Mr}$. Harvey was in vited from Paris to do a really superb series of sculp tures for the Lion House. His work was done so faithfully and so well that today it stands fairly beyond the reach of hostile criticism. No one-so far as we know-has any fault to find with the four sitting lions in marble that guard the doors of the two entrances of the Lion House, which certainly strike a happy medium between the demands of practical architecture and zoölogical realism.

Many of the largest and most noted animal sculptures now to be seen in our leading American cities were modeled in the Zoölogical Park. Proctor immortalized old "Sultan" in the four colossal lion figures, each 12 feet long, that recline at the base of the McKinley

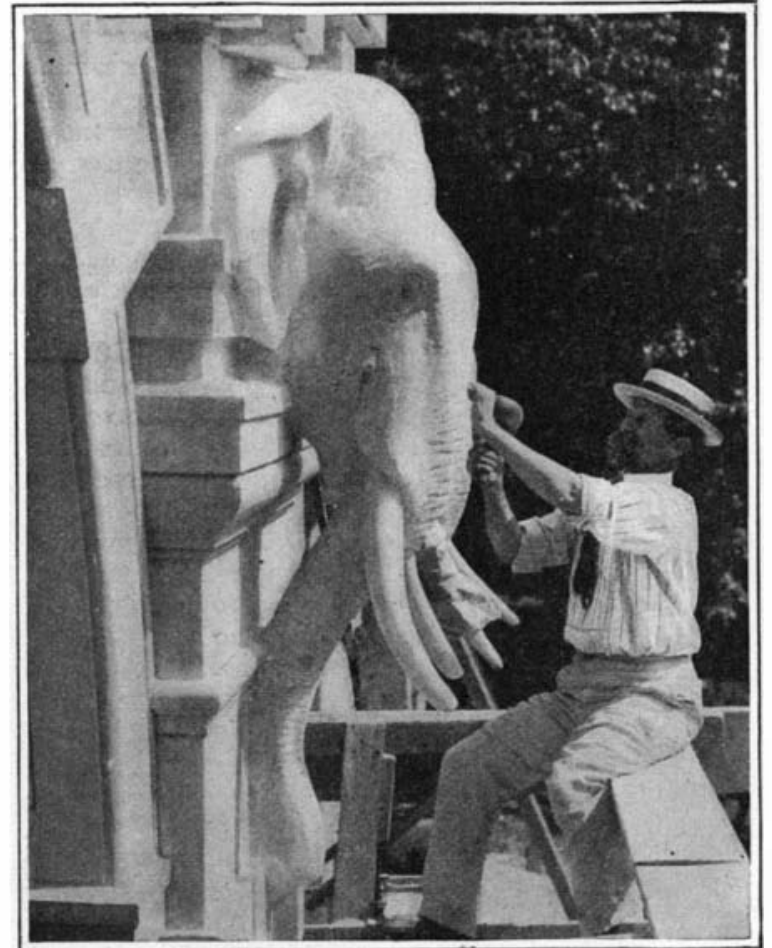

Mr. Proctor working on head of Indian elephant in front of the elephant house monument in Buffalo. Our finest 'bull bison was modeled by Mr. Proctor in a little house that he built for himself for winter use in the buffalo corral, and the great bronze buffaloes that command the approaches to the bridge over Rock Creek, in Washington are the result.

On the south side of our Elephant House, Mr. Proctor's life size heads of our Indian elephant, "Gunda," are most striking adornments. According to the regulations, Mr. Proctor's life-size model in plaster was to have been cut in stone by the mechanics of a contractor; and this was done, and turned over as "finished." The result was-two blocks of stone totally devoid of the vital spark of life.

And then, contrary to the natural requirements of the game, Mr. Proctor threw off his eoat donned overalls, climbed upon the scaffold and with mallet and chisel wrought upon those dead blocks of limestone until the living elephant stood forth. It was wonderful to see the spirit of old Gunda come forth from under that chisel, like a dim likeness being sharpened and made a "close-up" on a screen.

The African elephants, on the north entrance to the Lion House, were modeled by Mr. Charles R. Knight, and fortunately for him, the workmen were successful in catching and translating the spirit of his model, by which he was saved from the rough experience of $\mathrm{Mr}$ Proctor. Those two pairs of elephant heads strikingly establish forever the fact that there is not the slightest necessity or excuse for departing from the form and texture of the living model in sculptured wild anmals that are intended as adjuncts or ornaments for great architectural work. In fact, the strictly architectural lions in front of the New York Public Library have served their full purpose in demonstrating the long-smouldering aversion of the public to grotesque wild animals in public places.

Many beautiful sculptural groups of wild animals have been produced in the park and today stand in obscure cabinets, unknown save to the sculptor and the director. There are some that deserve to be born in the large, and in bronze or marble. I have particularly in mind a fine group of American bison by Miss Anna Vaughn Hyatt, whose life-size bronze statue of old "Sultan" adorns Dayton, Ohio, and a charming group of mountain goats by she who once was Margaret Weischman.

One of the most interesting of Zoölogical Park animal painters is Paul Herzel, who works month in and month out on elk and deer. The park is literally his studio, and when he is at work visitors enjoy the rare treat of seeing a real artist at work on a real painting. not a sketch in oil, but which they know will presently be finished in the park and taken straight away to receive its gold frame. 


\section{Danger!}

$\prod_{\text {better than most men }}^{\text {HE physician knows }}$ how the majority of us death, and one of the medicel fratern ical fraternity, Dr. Theron of New York City, has recently devised a warning signal which he confidently believes will go a long way towards lessening grade-crossings catastrophes - using to this end an emblem or signal calculated to a rouse great apprehension. As statistics show, accidents at railway crossings claim thousands of lives annually, which are sacrificed either because of heedless ness or the ineffectiveness

of the run of signals rommonly employed. All too cften pedestrians and autoists fail to hear the cauthoning bell, and this is particularly so if the man at the wheel of a car has his hearing deadened by the noise of the motor's engine. Time and again, the "joy rider" and others of a kindired careless tendency ignore crossing lights and take a peculiar pleasure in rushing by the fiagman unmindful of the fact that his mission is to save them and not to interfere with their proper progress.

As Dr. Kilmer says, denial to the contrary, "People do, indeed, fear death, and the risks they take in inviting disaster are not risks, as they understand them. They risks, as they understand them. They realize their peril until it is too late." Therefore, this physician has produced a safety device which suddenly confronts the venturesome with a ve of the skeleton which is evidence at the desired place or moment either by day or night.

This is achieved by depicting upon sheet metal, coated in dead black, a life-sized skeleton by means of luminous paint, which shows white by day and ominously lurid at night. In the case of a railroad crossing, the warning sign would ordinarily lie and below the highway level in a sultable recess, and would be swung vertically into place by the functioning of a small electric motor which would be called into action by the approaching train closing the operative circuit. Similarly, after the tracks have been cleared, and a second circuit closed, with motor reversed, the effigy sinks irom sight.

The inventor suggests that a similar startling warning be placed at any dangerous curve; the sign being continually in evidence and attached to a post placed at the side of the road far enough in advance of both approaches to the turn. Dr. Kilmer is satisfied that in this way it would be possible to drive home quickly and positively to the autoist's mind a realization of the hazard ahead.

\section{A Small-Space Tractor}

A TRACTOR specially designed for use on small farms has been recently initroduced by an apolis manufacturer of gasoline engines. Weighing only 700 pounds and only 84 inches in length this trac tor will do practically everything that a horse will do on the farm and may be used as a stationary engine wherever it may travel under its own power.

A one, two or three-row cultivator may be used with this tractor as well as a small turning plow for breaking ground in a garden or truck patch. It will also pull a oneshonse mowing machine, a one, two or three-row gang seeder, a harrow, pulverizer or a drag Sprayer equipment may be pulled through orchards with it and a great deal of time will be saved in actua

A New Method of Filling the Silo

$A$ NEW məthod of filling with this permethod two or three neigh bors can fill their own silos with less delay than where several have to club together as in the old way. The old way, with the cutter and blower combined at the silo and a corn harvester in the field, necessitated a great deal of helpalmost as much as at thrashing time; and in most communities many farmers had then to exchange work in order to insure each other of

der to insure each other of
suffient help.

The practical objections to this old way were that there was a great loss of time that could not be profitably used. Belts would break, cutter knives would get dull, nuts would come off, the engine would fai to keep up power and a hundred other things might happen. In the event that an accident did happen all of the men were laid off and seventeen men and the same number of horses laid off, an hour counts up a great deal of labor and expense as time is money these days. Moreover, twine for the harvester was an added expenditure and three or four pitchers were employed in the field to "pitch" the bundles from the ground, where the harvester had dropped them, up to the wagons which would take them to the barn. This is hard work and work that most men are glad to see done away with. Also, the silo was filled so fast that it did not have time to settle while filling was going on. This meant that after the silo was filled, it settled about six feet and that the whole of its capacity was not utilized.

The new way consists of a corn harvester to which is attached a cutter, the whole mechanism being run by a gasoline engine. The cut corn is delivered over to a wagon with a triple or quadruple bed on it. It will be seen that no twine is needed and furthermore, a minimum of engine horse-

spraying operations. At the draw bar this tractor develops one and one-half horse-power and used as a stationary engine will develop four horse-power on the belt.

A one cylinder, 4-cycle motor is used in this tractor. The gasoline tank has a capacity. of $11 / 2$ gallons. The tractor has a positive clutch control for each drive wheel. By releasing one clutch and permitting the other to work the tractor will pivot on one wheel. The width of the machine is $171 / 2$ inches and is 3 feet in height. It has one speed forward with a range of one to four miles per hour. The speed recommended for plowing is $21 / 2$ miles per hour. It is equipped with interchangeable bull wheels with quick detachable rims.-Allen P. Child.

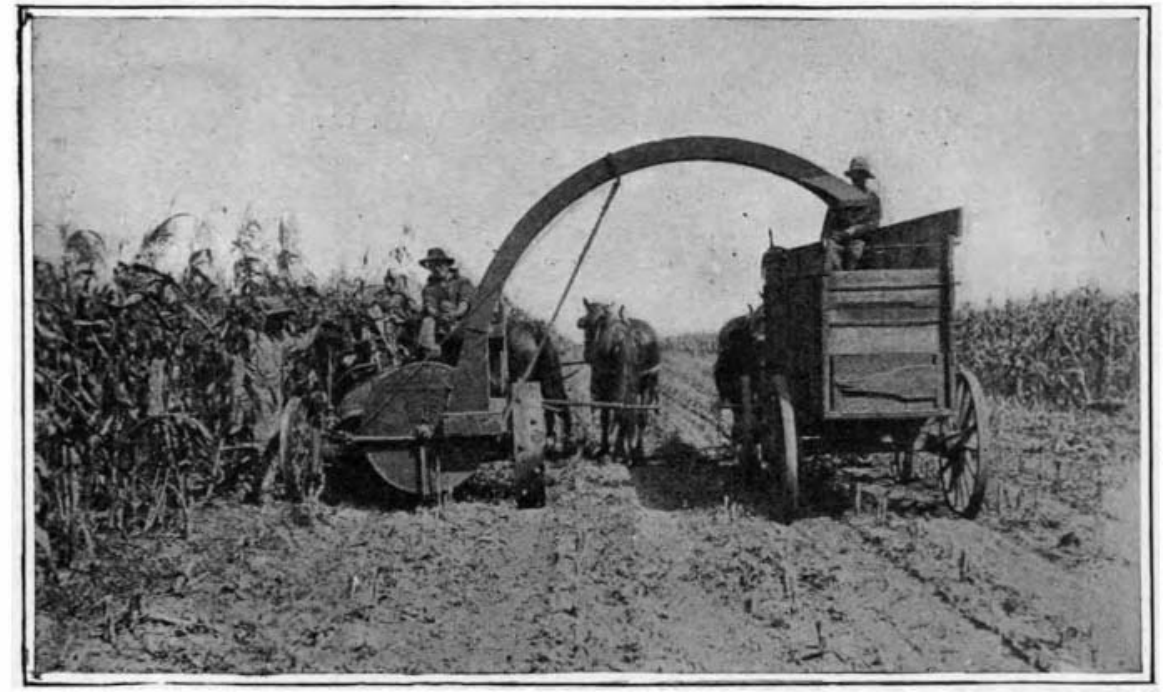

The harvester that delivers cut corn from the stalk to the wagon-

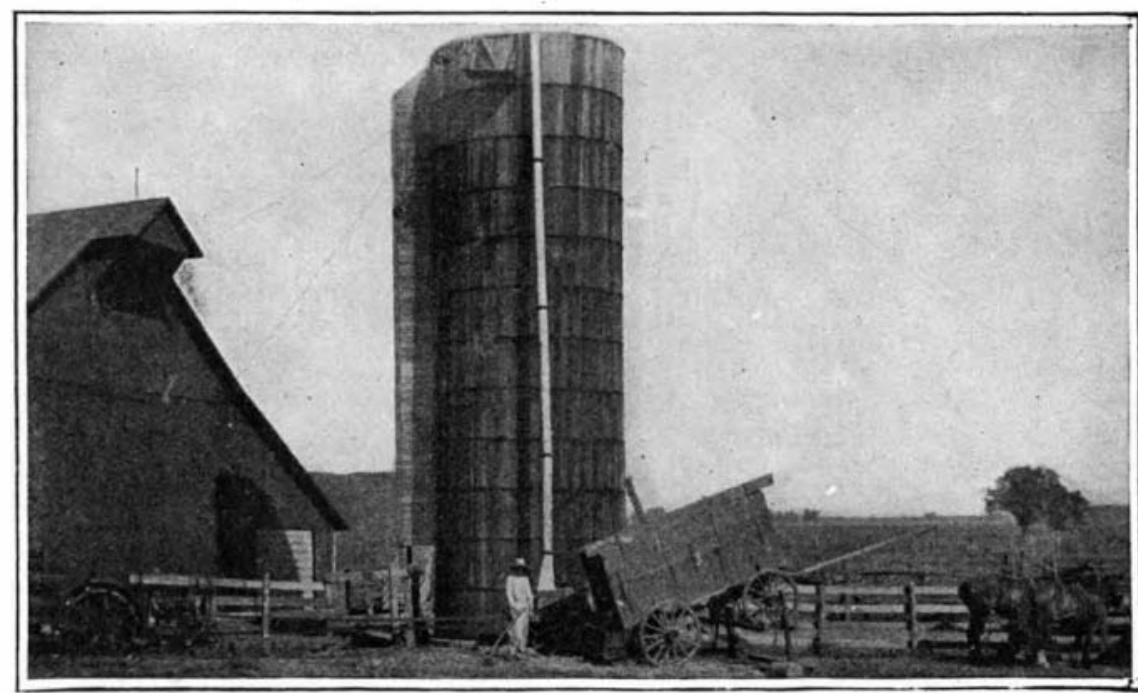

And the blower that packs it away in the silo against the coming of wintes 


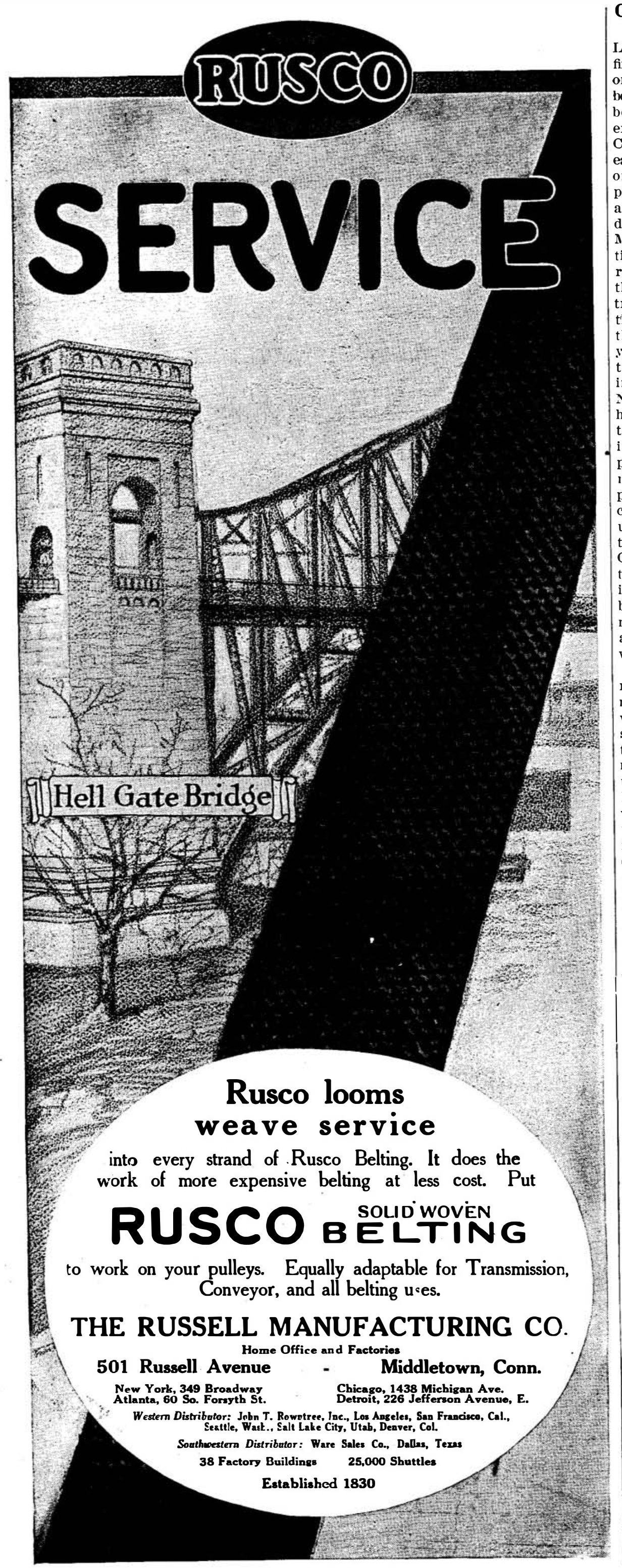

Coöperation and Industrial Progress (Continued from page 142) Labor are friends, not enemies. We are finding that the objects we are after are one, and that if this common object is to be obtained our method of approach must be along the same line. Capital cannot exist without Labor, and Labor without Capital is helpless. The development of each is dependent upon the coöperation of the other. Furthermore, through employee representation Capital and Labor are finding a very pleasant mutual understanding of each other's problems. Iany advocates of employee representation speak of the great benefits to be derived when the men at large understand the problems of management. This is true, but it is also equally important for the management to become educated in vears, when an employer ruled one or two hundred workmen, he knew his men inclivilually, and they understood him. Now, on the other hand, the corporation has replaced the indiviclual employer and the employees are numbered by thousands instead of hunclrels. It is therefore, impossible for the managers of a business to maintain personal contact with their employees. Industry has gained more efficiency through the development of large units, but the old personal contact beCivilization cannot affor to do without the economy of large production, and it is looking to employee representation to bridge the present gap and to bring the men into contact with the management and the management in direct contact with the men.

Those men who object to employe representation argue that employees are more interested in high wages; that they will elect unclesirable or incapable representatives; that they wil bre that it is merely an invitation looking toward the ultimate establishing of a closed shop. while it may be argued that the point of while it may be argued that the point of
view I have followed is a matter of opinview I have followed is a matter of opinion, no one has suggested a more condifferences between employers and employees. Secondly, our experience indicates that as often as not, the men ask for shorter hours rather than higher wages. They are interested in living happily and they feel that employee representalivelihood:

To others who claim that a group of American employees will not elect men capable of upholding the confidence re posed in tinem, I quote figures to indicate the stable characteristics of men chosen by the employees of my company as their representatives. The average of these representatives throughout the company are married. Their average employment with the company is over seven years, and a large number own their own homes or stock in the company. They are required by the plan to be American citizens, but that has not prevented the elecborn in foreign countries, some of whom have proven themselves in common council far above the average ability. I do not pretend to say that we do not have any radicals among the number, but their presence has only served to make the discussion keener and to prove to us that our plan was really democratic in basis. The men, of their own free will, have chosen responsible representatives whose opinions are valuable for

A New Method of Filling the Silo (Continued Jrom page 135)

an eight horse-power engine but the feeding must be proportioned to the size of the blower. By means of an iron rod running from the blower to the wagon elevator, the engine operating the blower also gradually hoists the wagon. A man with a pitchfork shoves the cut fodder rom the wagon out into the conveyor where it is fed into the silo.

In the silo one man is able to distribte the fodder and tramp it. One reason or this is that the silo is filled rather slowly, thereby giving the fodder ample time to settle; and when the last is run $\mathrm{n}$, the remainder in the silo is settled all will and the silo can be filled to the top.

Two 100-ton silos were filled on opposite sides of the road in northern Indiana. The usual work took twenty-five man-days or 250 man-hours which at forty cents per hour means $\$ 100$ or one dollar per With the new method the silo was flled with 150 man-hours of labor which at the same rate would be $\$ 60$ or sixty cents per ton.-I. J. Mathews.

Gas and Steel

(Continued from page 136)

change taking place while the steel is undergoing a change in temperature. One of the most important points 10 be given careful attention in all heat treating operations, is that of the "critcal range" of the steel, known as the "upper" and "lower" critical range. These values are not constant but vary according to the carloon content in the steel. The lower the percentage of carbon the greater the difference 'between these ranges. As the carbon content increases until at 0.85 per cent carbon they merge into one.

The significance of this characteristic in the steel is that during the period of heating between the lower and upper critical range a transformation is rapidly taking place in the constituents of the steel, which begins at the lower-critical range, and is completed at the upper critical range. In steel containing 0.85 per cent carbon, this transformation takes place immedlately, while for percentages above this

It is important, therefore, to understand this chamacteristic of steel if the best success is to be obtained in all healt treat ing work. For complete anneting and hardening it is necessary to know the upper critical ranges in orcler not to excrerl that point. Heating and cooling give full and complete results and exceeding it more than 50 degrees $F$. will likewise produce inferior work, by in creasing the granular structure of the steel and thus causing brittleness.

\section{Forging}

There is prolably no heat treating operation in use in which the principles of correct heat application a re more abused than that of forging. Here again one would conclude from observing the majority of forging fires in operation that speed and not quality is the aim of the manufacturer. In the majority of forging work today, the steel is heated in oil-fired furnaces, the coal and coke fire thaving been abandoned on account of their slowness and irregular heating of the metal. A large number of forging furnaces are "makeshift" affairs constructed by a mason with an oil burner applied at one or both ends with little or no thought for economy or quality of the finished product. Such furnaces will produce uneven heating especially where the flame impinges directly on the work nearest the burner.

One of the greatest faults with modern forging work is found in the desire for rapid heating. Under the action of a very intense heat the steel is made to "run" or drip on the exterior before the nterior has become properly soaked, consequently there exists a core in the bar which when placed under the hammer does not forge properly. It is very Im(Continued on page 146) 